\title{
Peran anggota Satuan Reserse Kriminal dalam menanggulangi kejahatan jalanan
}

\section{The role of the Criminal Reserse Unit Members in tackling road crime}

\author{
Farouk Ashadi Haiti \\ Program Studi Magister Kajian Ilmu Kepolisian, Sekolah Pascasarjana Universitas Airlangga \\ Surabaya, 60286, Jawa Timur, Indonesia \\ E-mail: farouk.ashadi.haiti-2015@pasca.unair.ac.id
}

\begin{abstract}
Abstrak
Tujuan penelitian ini yaitu untuk menganalisis faktor-faktor apakah yang menjadi penyebab terjadinya kejahatan jalanan di wilayah Polres Pelabuhan Tanjung Perak Surabaya dan untuk menganalisis upaya Satreskrim Polres Pelabuhan Tanjung Perak Surabaya dalam Penanggulangan Kejahatan Jalanan. Metode penelitian yang digunakan yaitu deskriptif kualitatif yang bertujuan untuk mendeskripsikan apa-apa yang saat ini berlaku. Sumber data dalam penelitian ini menggunakan wawancara kepada Kanit Reskrim Polres Pelabuhan Tanjung Perak Surabaya dan Anggota Satreskrim Polres Pelabuhan Tanjung Perak Surabaya. Hasil penelitian menjelaskan bahwa faktor yang mempengaruhi terjadinya kejahatan jalanan yaitu faktor ekonomi, faktor lingkungan dan faktor teknologi. Upaya Upaya preemtif dilakukan dengan bekerja sama dengan Binmas. Upaya preventif dengan menggalakkan program kring reserse dan Upaya represif dilakukan dengan cara menjaring dan memberantas premanisme dan berbagai sindikat kejahatan jalanan, serta menindak tegas dengan tembak di tempat pelaku kejahatan jalanan.
\end{abstract}

Kata kunci: peran; satuan reserse kriminal; kejahatan jalanan; kriminalitas; kontrol sosial

\begin{abstract}
The purpose of this research is to analyze the factors that be the cause in the harbor police tanjung perak surabaya and to analyze it a unit of harbor police criminal tanjung perak surabaya in response to the street crimes. Research methods that were used descriptive namely qualitative aimed at described all that when this is true of the source of data in this research using interviews on the head of harbor police criminal detective tanjung perak surabaya and members of harbor police criminal detective tanjung perak surabaya. The results of the study explained that of factors affect the street crimes that is economic factors, environmental factor and factors technology.Efforts efforts preemtif done with cooperating with police a community facilitator, the preventive efforts with promoting the program kring criminal detective and efforts repressive done by means of capture and eradicate thuggery and various syndicate street crimes, and take a strict with shoot on place the street crimes.
\end{abstract}

Keywords: role; criminal investigation unit; street crimes; crime; social control

\section{Pendahuluan}

Kompleksitas masalah sosial di kota besar selalu menjadi topik yang dibicarakan dalam berbagai seminar dan lokakarya untuk mencari solusi, termasuk di media, baik cetak maupun elektronik (Abdulsyani, 1987). Kriminalitas telah menjadi ketakutan besar dan mendapat perhatian penting diberbagai belahan dunia (Allen, 1996; Kelly, 2000; Fajnzlber et al, 2002; Brush, 2007; Choe, 2008). Wilayah hukum Polres Pelabuhan Tanjung Perak Surabaya yang membawahi 5 Polsek jajaran antara lain Polsek Asemrowo, Polsek Kenjeran, Polsek Krembangan, Polsek Pabean Cantikan, dan Polsek Semampir. Dari 5 wilayah Polsek jajaran tersebut Wilayah Kecamatan Semampir adalah termasuk 3 termiskin di Surabaya.

Di dunia modern, tindakan kriminal telah menjadi ketakutan besar dan telah mendapatkan kesadaran penting dalam hal beberapa penelitian yang dilakukan oleh Allen (1996), Kelly (2000), Fajnzlber et al (2002), Brush (2007) dan Choe (2008). Sudah ada studi kuantitatif (Becker, 1968; Ehrlich, 1973; Chiu \& Madden, 1998; Bourguignon, 2001; Imrohoroglu et al, 2000) dalam kriminologi untuk memeriksa dampak kemajuan sosial pada kecenderungan kejahatan dan bentuk-bentuk kejahatan. 
Penelitian dari Setijaningrum (2017) menjelaskan bahwa kelompok miskin terbesar di Kota Surabaya berada di 3 Kecamatan, yaitu Kecamatan Semampir, Kecamatan Tambaksari, dan Kecamatan Simokerto. Kecamatan Semampir terdiri dari 5 kelurahan dengan $60.41 \%$ keluarga miskin, Tambaksari terdiri dari 6 kelurahan dengan $12.47 \%$ keluarga miskin, sedangkan kecamatan Simokerto terdiri dari 5 kelurahan dengan $41.82 \%$ keluarga miskin.Hal ini selaras dengan berbagai penelitian lain yang menunjukan bahwa kesulitan ekonomi dan kejahatan selalu menjadi masalah yang saling berkaitan meski adapula yang sepenuhnya berlawanan (Imran et al, 2018, Brady \& Burton, 2016).

Dengan keadaan faktor kemiskinan yang tinggi ini diduga menjadi tingginya angka kriminalitas di wilayah Polre Pelabuhan Tanjung Perak. Selain itu demografis wilayah yang berdekatan dengan Jembatan Suramadu, penulis duga juga memberikan dampak terhadap peningkatan aksi kriminalitas, karena berdasarkan catatan Polres Pelabuhan Tanjung Perak, rata-rata pelaku aksi curanmor selalu mempunyai niat atau rencana untuk melarikan barang curiannya ke wilayah Madura melalui Jembatan Suramadu.

Tujuan penelitian ini yaitu untuk menganalisis faktor-faktor apakah yang menjadi penyebab terjadinya kejahatan jalanan di wilayah Polres Pelabuhan Tanjung Perak Surabaya dan untuk menganalisis upaya Satreskrim Polres Pelabuhan Tanjung Perak Surabaya dalam Penanggulangan Kejahatan Jalanan.

\section{Metode Penelitian}

Jenis Penelitian ini adalah deskriptif kualitatif yang bertujuan untuk mendeskripsikan apa-apa yang saat ini berlaku. Sumber data dalam penelitian ini menggunakan wawancara kepada Kanit Reskrim Polres Pelabuhan Tanjung Perak Surabaya dan Anggota Satreskrim Polres Pelabuhan Tanjung Perak Surabaya. Teknik pengmpulan data dalam penelitian ini meliputi wawancara dan dokumentasi. Teknik analisis data yang digunakan dalam penelitian ini adalah menggunakan langkah-langkah terdiri dari pengumpulan data, reduksi data, penyajian data dan mendiskusikan data dengan studi terdahulu dan teori yang relevan dengan topik yang dikaji.

\section{Hasil dan Pembahasan}

\section{Faktor-faktor penyebab terjadinya kejahatan jalanan di wilayah Polres Pelabuhan Tanjung Perak Surabaya}

Faktor pendidikan merupakan salah satu faktor pendorong seseorang untuk melakukan suatu tindak pidana pencurian. Hal itu disebabkan oleh tingkat pengetahuan mereka yang kurang terhadap hal-hal seperti aturan yang dalam cara hidup bermasyarakat. "Tingkat pendidikan dianggap sebagai salah satu faktor yang mempengaruhi seseorang berbuat jahat (mencuri, memeras, merampok, dsb), pendidikan merupakan sarana bagi seseorang untuk mengetahui mana yang baik dan mana yang buruk. Dengan melakukan suatu perbuatan apakah perbuatan tersebut memiliki suatu manfaat tertentu atau malah membuat masalah/kerugian tertentu." Jika dikaitkan dengan usia pertama kali anak terpaksa putus sekolah relatif berbeda-beda. Pada keluarga yang paling miskin, menemukan ada kecenderungan usia putus sekolah anak makin dini, karena mereka sejak kecil sudah harus membantu orang tuanya bekerja (Suyanto 2013).

Berdasarkan dari hasil wawancara dengan para pelaku kejahatan jalanan saat BAP, salah satu diantaranya mengatakan:

“Aku mek tamatan SD Pak, kerjo opo maneh lek gak ngene. Kerjo pabrik yo gak di trimo (aku hanya tamatan SD Pak, kerja apa lagi kalau tidak begini, Kerja Pabrik ya tidak diterima).”

Selain itu, hal tersebut juga menunjukkan daya tangkap orang tersebut mengenai mana hal yang baik dan yang buruk juga kurang karena input pendidikan yang tidak ada selain input pengetahuan di jalanan tempat ia hidup. 
Dalam diri individu seseorang tercipta suatu mental atau karakter dimana karakter tersebut sangat berpengaruh terhadap tingkah laku manusia. Dari pendapatnya Samuel Yochelson mengungkatpkan bahwa: "Ada hubungan antara kepribadian dan kejahatan yaitu kepribadian dari penjahat dan bukan penjahat, memprediksi tingkah laku, menguji tingkatan dimana dinamika-dinamika kepribadian moral beroperasi dalam diri penjahat, dan perbedaan antara tipe individual pelaku kejahatan".

Seseorang yang tingkah lakunya baik akan mengakibatkan seseorang tersebut mendapatkan penghargaan dari masyarakat, akan tetapi sebaliknya jika seseorang bertingkah laku tidak baik maka orang itu akan menimbulkan kekacauan dalam masyarakat. Mereka yang dapat mengontrol dan mengembangkan kepribadiannya yang positif akan dapat menghasilkan banyak manfaat baik itu bagi dirinya sendiri maupun bagi orang lain. Sedangkan mereka yang tidak bisa mengontrol kepribadiannya dan cenderung terombang-ambing oleh perkembangan akan terus terseret arus kemana akan mengalir. Entah itu baik atau buruk mereka akan tetap mengikuti hal tersebut. Terdapat pula penyebab seseorang melakukan tindak pidana, seperti yang telah disebutkan diatas bahwa keinginan manusia merupakan hal yang tidak pernah ada batasnya.

Tabel 1.

Usia dini rata- rata anak putus sekolah

\begin{tabular}{ccr}
\hline Keterangan & Klasifikasi & Persentase \\
\hline \multirow{2}{*}{ Jenis kelamin } & Laki-laki & $40.7 \%$ \\
\cline { 2 - 3 } & Perempuan & $59.3 \%$ \\
\hline \multirow{2}{*}{ Umur } & $14-15$ tahun & $34.0 \%$ \\
\cline { 2 - 3 } & $16-17$ tahun & $36.0 \%$ \\
\cline { 2 - 3 } $\begin{array}{c}\text { Dalam keluarga, responden } \\
\text { merupakan anak yang ke- }\end{array}$ & Anak ke-2 & $30.0 \%$ \\
\cline { 2 - 3 } & Anak ke-3 & $40.0 \%$ \\
\cline { 2 - 3 } & Anak ke-4 & $50.0 \%$ \\
\hline \multirow{3}{*}{ Responden putus sekolah pada saat } & $10.0 \%$ \\
\cline { 2 - 3 } & Belum lulus SD & $20.0 \%$ \\
\cline { 2 - 3 } & Sudah lulus SD & $45.3 \%$ \\
\cline { 2 - 3 } & Belum lulus SMP & $24.7 \%$ \\
\cline { 2 - 3 } & Sudah lulus SMP & $10.0 \%$ \\
\cline { 2 - 3 } Usia responden saat putus sekolah & 9 tahun & $9.3 \%$ \\
\cline { 2 - 3 } & 10 tahun & $8.7 \%$ \\
\cline { 2 - 3 } & 11 tahun & $15.3 \%$ \\
\cline { 2 - 3 } & 12 tahun & $34.0 \%$ \\
\cline { 2 - 3 } & 13 tahun & $10.7 \%$ \\
\cline { 2 - 3 } & 14 tahun & $8.0 \%$ \\
\hline
\end{tabular}

Sumber: Masalah Sosial Anak (Bagong Suyanto, 2013)

Tabel 1 menunjukkan bahwa usia anak putus sekolah, yang paling dini adalah 9 tahun (9,3\%). Dari 150 anak yang di-teliti, 8,7\% mengaku putus sekolah pada saat berusia 10 ta-hun, sebanyak 15,3\% putus sekolah pada saat berusia 11 tahun, dan $34 \%$ pada saat mereka berusia 12 tahun. Ini berarti, cukup banyak responden yang putus sekolah pada saat mereka belum lulus SD. Sebagian besar anakanak yang diteliti mengaku pu-tus sekolah selepas mereka lulus SD (45,3\%). Namun tidak sedikit responden mengaku (20\%) terpaksa putus sekolah walaupun mereka belum lulus SD. Hanya 10\% responden yang mengaku putus sekolah setelah lulus SMP, dan seba-nyak 24,7\% responden mengaku putus sekolah ketika belum lulus SMP. Bagi anak- anak dari keluarga miskin, putus sekolah di tengah jalan dan kemudian memilih segera bekerja atau sekadar membantu orang tua mencari nafkah sering kali menjadi pilihan yang terpaksa diambil, tetapi banyak hal yang tidak baik yang diakibatkan renndahnya pendidikan di usia dini yakni rentannya mereka terjerumus tindak kriminal sebagai alternatif mudah, tanpa ijasah untuk mendapat uang berlebih dalam sekejap. 
Dari wawancara penyidik saat BAP diketahui bahwa adanya pernyataan yang tersangka bahwa:

"Pada awalnya saya enggak ada niatan buat ambil motor orang, tapi karena waktu itu saya lihat ada motor yang sudah siap pakai (mesin sudah nyala) dan pemiliknya enggak kelihatan jadi saya ambil saja motornya"

Dari hal tersebut, dapat dihubungkan dengan faktor yang melatar belakangi tindak pencurian tersebut misalnya apabila dalam diri seseorang mempunyai mental seorang kriminal, maka dalam hal pemenuhan kebutuhan hidupnya, mereka tidak mau bekerja. Ada kecenderungan untuk mencari uang dengan jalan cepat yaitu dengan jalan mencuri. Kemudian walau sudah pernah dihukum namun masih mengulangi tindak pidana tersebut. Karena mereka beranggapan bahwa hanya dengan jalan itu mudah untuk mendapatkan uang.

Kemiskinan merupakan sebuah fenomena yang tidak dapat ditolak di setiap negara. Hingga sekarang belum ada jalan kelaur untuk menyelesaikan fenomena tersebut. Plato mengemukakan bahwa disetiap negara dimana banyak terdapat orang miskin, dengan secara diam-diam terdapat banyak penjahat, pelanggar agama dan dan penjahat dari bermacam-macam corak.

Dalam Kongres PBB ke-8 Tahun 1990 di Havana, Cuba, yang dikutip oleh Barda Nawawi Arief, mengidentifikasi faktor-faktor kondusif penyebab kejahatan, khususnya dalam masalah "urban street crime", salah satunya antara lain Kemiskinan, pengangguran, kebutahurufan (kebodohan), ketiadaan/kekurangan perumahan yang layak dan sistem pendidikan serta sistem latihan yang tidak cocok/serasi.

Faktor ekonomi merupakan faktor yang bersumber dari luar diri manusia. Seseorang umumnya melakukan kejahatan pencurian untuk menguasai benda orang lain sehingga nilai ekonomis dari benda tersebut dapat dimanfaatkan oleh pelaku kejahatan jalanan. Maka seseorang yang kurang atau rendah tingkat kesejahteraan ekonominya akan lebih rentan terhadap kasus kejahatan jalanan.

Menurut teori Marx, kriminalitas hanya suatu produk dari suatu sistem ekonomi yang buruk, terutama dari sistem ekonomi kapitalis, maka tugas kriminologi ialah menunjukkan hubungan yang sesungguhnya antara bangunan ekonomi masyarakat itu dengan kejahatan (Abdulsyani, 1987; Santoso \& Eva, 2005).

Faktor penyebab timbulnya kejahatan karena masalah ekonomi dalam kenyataannya ternyata bukan hanya suatu ungkapan yang sering menjadi topik dari berbagai diskusi ilmiah mengenai penanggulangan kejahatan. Hal tersebut dari hasil penelitian penulis, merupakan suatu kenyataan seperti ini seringkali terjadi pada sebagian masyarakat miskin. Seperti halnya yang terjadi pada wilayah hukum Polres Pelabuhan Tanjung Perak Surabaya yang membawahi 5 Polsek jajaran antara lain Polsek Asemrowo, Polsek Kenjeran, Polsek Krembangan, Polsek Pabean Cantikan, dan Polsek Semampir. Dari 5 wilayah Polsek jajaran tersebut Wilayah Kecamatan Semampir adalah termasuk 3 termiskin di Surabaya sebagaimana penelitian dari Setijaningrum (2017). Dalam Penelitian tersebut dinyatakan bahwa Kelompok miskin terbesar di Kota Surabaya berada di 3 Kecamatan, yaitu Kecamatan Semampir, Kecamatan Tambaksari, dan Kecamatan Simokerto.

Kecamatan Semampir terdiri dari 5 kelurahan dengan $60.41 \%$ keluarga miskin, Tambaksari terdiri dari 6 kelurahan dengan $12.47 \%$ keluarga miskin, sedangkan kecamatan Simokerto terdiri dari 5 kelurahan dengan $41.82 \%$ keluarga miskin. Kemiskinan merupakan suatu ketidakmampuan (lack of capabilities) seseorang dalam memenuhi kebutuhan minimum seperti pangan, sandang, papan, pelayanan kesehatan, pendidikan, penyediaan air bersih dan sanitasi.

Penelitian ini menunjukkan bahwa kebutuhan prioritas kelompok miskin yaitu: (1) pendidikan, (2) kesehatan, (3) perumahan, (4) sembilan bahan pokok, (5) air bersih, (6) kemudahan administrasi, (7) pelatihan keahlian, (8) lapangan pekerjaan. Dapat disimpulkan bahwa kelompok miskin menempatkan 
kebutuhan pendidikan, kesehatan, dan perumahan sebagai tiga prioritas kebutuhan teratas. Pelaku kejahatan jalanan yang banyak dilakukan oleh masyarakat miskin di wilayah hukum Polres Tanjung Perak, dilakukan oleh masyarakat miskin untuk memenuhi kebutuhan mereka atau keluarganya, hal ini jelas akibat dari keberadaan ekonomi yang tidak menentu yang menimbulkan melakukan kejahatan. Dari beberapa penanganan kasus kejahatan jalanan oleh Polres Pelabuhan Tanjung Perak Surabaya, diketahui bahwa seseorang dapat tersesat oleh perekonomian yang mereka ciptakan sendiri untuk melakukan hal-hal yang tidak seperlunya dilakukan oleh orang- orang yang berakal sehat.

Jadi suatu keadaan keluarga yang miskin akan membawa seseorang untuk menuju pada kehidupan yang lebih layak dari kehidupan yang sebelumnya, sehingga bagi mereka yang ingin cepat meraihnya akan cenderung berjalan di jalan yang kurang terpuji. Bila dilihat dengan pendapatan sehari-hari dari perilaku kriminal yang ditimbulkan oleh masalah ekonomi, maka disimpulkan mengenai kondisi mereka diantaranya sebagai berikut: (1) Jumlah pendapatan yang diperoleh sehari-hari tidak mencukupi kebutuhan mereka, yaitu mereka yang mempunyai pendapatan per hari Rp10.000,00 sampai dengan Rp20.000,00; (2) Jumlah yang diperoleh per minggu tidak mencukupi selama satu minggu; (3) Jumlah pendapatan yang diperoleh tidak seimbang dengan jumlah keluarga yang harus dibiayai; (4) Tidak mempunyai pekerjaan tetap yang dapat dijadikan sumber penghasilan (Efendi, 2005).

Oleh karena hal-hal tersebut di atas, jelas kiranya ada sekelompok masyarakat yang memang tidak dapat mencukupi atau memenuhi kebutuhan hidupnya, yaitu mereka harus mencukupi kebutuhan primer dan sekunder yang mau tidak mau harus mereka penuhi, seperti bahan pokok beras, lauk, perlengkapan dapur, dan pakaian. Hal ini harus tercapai guna kelangsungan hidup mereka sehariharinya. Namun, pendapatan yang mereka peroleh tidak seimbang dengan kebutuhan yang mereka harus penuhi.

Sedangkan untuk meningkatkan keterampilan sebagai penunjang ekonomi keluarga, serta memanfaatkan kesempatan-kesempatan yang disediakan, mereka ternyata adalah tipikal pemalas yang tidak mau berusaha maksimal untuk mencari sumber penghasilan dengan meningkatkan kualitas skill mereka padahal mereka juga mengetahui berbagai program pemberdayaan skill dari Pemkot Surabaya telah banyak disosialisasikan sampai tingkat terbawah yakni Rukun Tangga (RT). Selain itu keinginan mendapatkan hasil maksimal dalam waktu sekejap juga masih menjadi dambaan para pelaku kejahatan jalanan ketimbang menjalani proses pelatihan yang dianggap belum tentu bisa cepat mendatangkan penghasilan yang banyak dalam sekejap.

Beberapa contoh berikut merupakan hasil pemberkasan dari Pelaku Kejahatan Jalanan yang diantaranya terlibat kriminalitas karena faktor ekonomi. (1) (AA) seorang laki-laki yang berasal dari keluarga dengan mata pencaharian sebagai penjaga counter HP, AA seorang kepala keluarga melakukan pencurian motor di salah satu minimarket di wilayah Indrapura Surabaya; (2) (RS) seorang laki-laki berasal dari keluarga pengangkut barang di pasar (kuli) Pabean Surabaya. RS seorang kepala keluarga mencuri uang di pasar Pabean tempat dia bekerja; (3) (JW) seorang laki-laki berasal dari keluarga dengan mata pencaharian sebagai Kernet Angkutan Umum. JW seorang hidup dengan istri dan 3 anak melakukan kejahatan pejambretan di kawasan Ampel Surabaya; (4) (K) seorang laki-laki yang berasal dari keluarga dengan mata tidak tetap. (K) melakukan kejahatan penjambretan di wilayah Wonokusumo Surabaya. Kenyataan yang demikian mendukung peneliti berpendapat bahwa keadaan ekonomi keluarga atau seseorang yang lemah mampu mempengaruhi timbulnya hal-hal tersebut di atas, dan pada akhirnya akan mempengaruhi timbulnya suatu kejahatan.

Selain faktor ekonomi, faktor lingkungan merupakan salah satu faktor yang memiliki pengaruh atas terjadinya tindak kejahatan jalanan. Seseorang yang hidup/tinggal di dalam lingkungan yang mendukung untuk dilakukannya pencurian, maka di suatu waktu ia juga akan melakukan tindak pencurian tersebut. Banyak hal yang membuat lingkungan menjadi faktor penyebab terjadinya suatu tindak kejahatan jalanan misalnya pencurian. Misalnya kebutuhan dalam pergaulan dengan teman sebaya, kontrol dari lingkunganyang kurang dan pergaulan dengan seseorang yang memiliki pekerjaan 
sebagai pencuri. Orang tua bertanggungjawab atas apa yang dilakukannya oleh anaknya, ada pepatah mengatakan bahwa "buah jatuh tidak jauh dari pohonnya" oleh sebab itu pola tingkah laku/kebiasaan orang tua di dalam rumah tangga menentukan bagaimana sifat seorang anak dalam pergaulannya. Selain itu bagaimana cara orang tua mendidik seorang anak juga mempengaruhi bagaimana sifat seorang anak di masyarakat. Pengakuan dari tersangka pencurian mengenai hal tersebut antara lain:

\begin{abstract}
"Ketika berada di rumah, saya malah merasa gak nyaman sama sekali. Tiap hari selalu dimari sama orang tua. Disuruh gini gitu. Makanya saya akhirnya jarang pulang dan males juga buat pulang. Selama gak pulang saya nginep di rumah temen-temen dan bisa bebas main-main sampai akhirnya kehabisan uang buat seneng-seneng. Dan akhirnya kita mencuri motor"
\end{abstract}

Oleh karena itulah orang tua memiliki peranan yang sangat penting dalam mencegah seorang melakukan tindak kejahatan.

Perkembangan global memiliki dampak yang positif bagi kemajuan suatu negara, sedangkan bagi individu perkembangan global merupakan suatu sarana untuk menunjukan bahwa dia adalah seseorang yang mampu memenuhi kebutuhan hidupnya dalam masa perkembangan global tersebut. Selain itu seseorang yang memiliki sesuatu (harta) yang lebih dipandang sebagai orang yang sukses, hal ini tentunya membuat setiap orang dalam masyarakat bersaing satu sama lainnya untuk menunjukkan bahwa dirinyalah yang paling unggul. Dan tidak dapat dipungkiri bahwa orang yang tadinya kurang mampupun akan ikut bersaing meskipun mengunakan cara-cara yang salah. Kebanyakan dari mereka lebih memilih cara yang praktis daripada harus bekerja lebih keras tanpa memikirkan resiko apa yang akan diterimanya kelak atas perbuatan yang telah ia lakukan.

Seperti halnya salah seorang pelaku pencurian kendaraan bermotor:

"Lihat orang lain punya barang- barang yang bagus bikin kepengen mas, jadi saya curi motor terus saya jual dan uangnya buat beli barang yang saya pengen tadi."

Kemajuan teknologi khususnya media massa juga turut serta mempengaruhi seseorang untuk berbuat jahat. Media massa memberikan rangsangan terhadap pemikiran-pemikiran seseorang dalam kehidupan bermasyarakat. Bahkan tidak jarang tayangan televisi memberikan contoh-contoh melakukan pencurian kendaraan bermotor, meskipun pada dasarnya tayangan tersebut bukan bermaksud untuk memberikan suatu contoh. Pemikiran dan daya tangkap masing-masing individu tentulah berbeda-beda pula, oleh sebab itu, tayangan televisi dapat memberikan suatu kesan yang buruk bagi seseorang.

Salah satu teori dalam krimonogi adalah teori "Differential Association" yang berlandaskan pada proses belajar, yaitu bahwa perilaku kejahatan adalah perilaku yang dipelajari. Menurut Sutherland, apabila perilaku kejahatan dipelajari, maka yang dipelajari tersebut meliputi (a) teknik melakukan kejahatan (b) motif-motif tertentu, dorongan, alasan pembenar dan sikap. Adapun demikian, salah satu preposisinya menyatakan bahwa komunikasi yang bersifat nirpersonal seperti melalui bioskop, surat kabar, secara relatif, tidak mempunyai peranan yang penting dalam terjadinya perilaku kejahatan. Pandangan tersebut, berbanding terbalik dengan hasil penelitian, di mana salah satu penyebab adanya peniruan dikarenakan adanya peniruan kejahatan begal di wilayah lain, termasuk pula peranan media massa yang memberitakan berbagai modus kejahatan jalanan tanpa adanya narasumber dari kepolisian yang menjelaskan secara berimbang, maka menurut wawancara dengan anggota Satreskrim Polres Pelabuhan Tanjung Perak Surabaya, bahwa hal tersebut kemungkinan akan bisa menimbulkan dampak negatif bagi masyarakat.

Selanjutnya dipaparkan pula faktor yang mempengaruhi terjadinya kejahatan jalanan dalam perspektif viktimologi, yakni ilmu pengetahuan tentang korban, di mana salah satu kajiannya adalah mencari sebab-sebab terjadinya viktimisasi. Berdasarkan hasil penelitian terdapat 3 (tiga) faktor utama yang mempengaruhi terjadinya kejahatan jalanan dalam perspektif Viktimologi (Angkasa \& Iswanto 2005; Waluyo, 2011). 
Perilaku korban yakni kurang waspada (hati-hati, mencurigai), kurang dapat menempatkan diri dalam membawa barang bawaan (membawa barang yang mecolok perhatian pelaku), kebiasaan korban (pulang pagi). Mandelsohn, membuat suatu tipologi korban yang diklarifikasikan menjadi 6 (enam) tipe, salah satunya adalah "The victim with minor guilt and the victm due to his ignorance", yakni korban dengan kesalahan kecil dan korban yang disebabkan kelalaian. Termasuk pula salah satu tipologi dari Steven Schafer, adalah "precipitative victims", yakni pelaku melakukan kejahatan karena tingkah laku yang tidak hati-hati dari korban mendorong pelaku melakukan kejahatan. Berkaitan teori di atas, maka perilaku korban di atas, pada dasarnya merupakan kualifikasi peranan korban yakni korban dengan kesalahan kecil dan korban yang disebabkan kelalaian. Korban di sini tidak menyadari bahwa dirinya membuat kesalahan kecil yakni tidak hati- hati atau waspada, di mana hal tersebut justru membawa akibat yang besar.

Kelemahan biologis dan psikologis, dalam hal ini yakni usia tua lebih berisiko menjadi korban (lebih mudah dilumpuhkan), perempuan lebih berisiko menjadi korban, sumberdaya manusia yang kurang, perasaan takut terlebih dahulu atau mudah takut saat digertak pelaku. Risiko korban menurut Separovic, salah satunya faktor pribadi, di sini termasuk faktor biologis (usia, jenis kelamin, kesehatan, terutama kesehatan jiwa). Hentig membagi tipe korban menjadi 13 (tiga belas) macam, salah satunya adalah "The Old", bahwa orang tua mempunyai risiko menjadi korban atas tindak pidana terhadap harta kekayaan. Di sisi lain terdapat kelemahan, pada jasmaninya atau terkadang mentalnya yang mulai lemah. Termasuk pula salah satu tipologi dari Steven Schafer adalah "Biologically weak victims", yakni siapa saja yang secara fisik atau mental lemah, misalnya orang yang sangat muda atau sangat tua dan orang yang tidak sadar menjadi targer kejahatan.

Berkaitan dengan hal di atas, terdapat 10 (sepuluh) kasus kejahatan jalanan yang menunjukkan umur korban diatas 55 tahun. Penurunan ketahanan fisik dan mental. Oleh karenanya korban di sini lebih dapat dilumpuhkan pelaku kejahatan begal yang berusia lebih muda, sehingga menjadi target yang menarik bagi pelaku. Salah satu tipe korban menurut Hans Von Hentig adalah "The Female", yakni wanita merupakan korban dengan bentuk kelemahan lain, bahwa di samping lemah jasmaninya (apabila dibandingkan dengan pria dan pelakunya biasanya juga pria) wanita juga diasumsikan mempunyai dan/atau memakai barang-barang seperti perhiasan yang mempunyai nilai ekonomis tinggi. Berkaitan hal dengan kasus kejahatan begal, terdapat 5 (lima) korban dengan jenis kelamin perempuan dan 8 (delapan) korban dengan jenis kelamin laki-laki. Sekalipun korban dengan jenis kelamin laki-laki lebih banyak, namun perempuan memiliki risiko yang lebih tinggi untuk dapat dilumpuhkan pelaku berkaitan dengan kelemahan fisik dalam melakukan perlawanan. Adapun berkaitan dengan sumber daya manusia yang kurang, dalam hal ini membawa pada akibat kekurang hati-hatian korban. Sedangkan perasaan takut terlebih dahulu atau mudah takut saat digertak atau diancam, dapat mempengaruhi terjadinya viktimisasi. Hal ini berkaitan dengan psikologis korban, di mana korban yang mudah merasa takut dan kemudian berhadapan dengan situasi yang membahayakan, tentunya mengakibatkan perlawanan korban lemah dan semakin mempercepat atau mempermudah pelaku melakukan kejahatan jalanan.

Faktor situasi dimana korban berada di tempat yang memungkinkan terjadinya kejahatan jalanan, korban berada dalam situasi dan kondisi yang tidak memungkinkan melakukan perlawanan, sehingga mempengaruhi psikologisnya (rasa takut). Sebagaimana dikemukakan Separovic, bahwa salah satu faktor risiko korban adalah faktor situasi, yaitu keadaan konflik, tempat dan waktu. Berkaitan dengan hal tersebut, pada dasarnya bahwa situasi tempat mempengaruhi terjadinya viktimisasi kejahatan jalanan, di mana korban berada pada situasi yang sulit untuk melakukan perlawanan. Adapun menurut Hans Von Hentig, salah satu tipe korban adalah the blocked, exempted, and fighting. Orang yang terhalang, bebas, dan suka berkelahi memunyai risiko yang berbeda untuk terjadinya viktimisasi. Orang yang terhalang diartikan sebagai individu yang berada dalam posisi dan kondisi sulit untuk keluar dari bahaya. Mereka yang termasuk dalam tipe ini adalah orang yang terperangkap dalam situasi yang tidak memungkinkan untuk melakukan pembelaan atau bahkan tindakan tersebut justru menimbulkan penderitaan yang lebih serius. 
Berkaitan dengan kejahatan jalanan, menunjukkan bahwa beberapa kasus kejahatan jalanan terjadi di wilayah yang sepi dan dapat diidentifikasikan sebagai wilayah yang rawan kejahatan. Namun demikian, di sisi lain beberapa kasus kejahatan begal justru terjadi di willayah yang ramai. Hal ini menunjukkan bahwa, terjadinya kejahatan begal tidak tergantung pada sepi atau ramainya suatu tempat, melainkan lebih pada tempat yang memungkinkan pelaku dapat melakukan kejahatan. Hal di atas, berkaitan dengan teori ekologis, di mana salah satunya adalah mobilitas penduduk. Mobilitas penduduk di sini dimaksudkan hanyalah mobilitas horizontal yang pada belakangan ini dengan jelas dapat dilihat peningkatannya. Hal ini terutama karena pengaruh sarana transportasi yang semakin meningkat.

Termasuk pula Shaw \& McKay berdasarkan hasil studinya, dia menyimpulkan bahwa angka kejahatan yang tertinggi terdapat di daerah pusat industri dan perdagangan, daerah yang paling miskin. Merujuk pada pendapat tersebut, beberapa kasus tempat terjadinya kejahatan jalanan di wilayah hukum Polres Pelabuhan Tanjung Perak terjadi di daerah perkotaan. Daerah perkotaan di sini identik dengan pusat perdagangan, sehingga mempengaruhi mobilitas penduduk, oleh karenanya menjadi tempat target (sasaran) bagi pelaku kejahatan jalanan. Hal ini diperkuat diperkuat pula dalam kajian Viktimologi bahwa pada daerah- daerah bisnis di pinggir kota, dan pada daerah-daerah bisnis kota kecil yang terdapat harta benda berharga, tindak pidana pencurian dengan kekerasan sangat mendominasi. Termasuk pula, terdapat kecenderungan berisiko untuk menjadi korban tindak pidana kekerasan di jalan-jalan umum. Ini disebabkan pertimbangan dari pelakunya mempunyai kesempatan lebih mudah untuk melarikan diri dibandingkan dengan di jalan-jalan kecil.

\section{Upaya Satreskrim Polres Pelabuhan Tanjung Perak Surabaya dalam penanggulangan kejahatan jalanan}

Upaya represif adalah suatu upaya penanggulangan kejahatan secara konsepsional yang ditempuh setelah terjadinya kejahatan (Arief, 2001). Penanggulangan dengan upaya represif dimaksudkan untuk menindak para pelaku kejahatan sesuai dengan perbuatannya serta memperbaikinya kembali agar mereka sadar bahwa perbuatan yang dilakukannya merupakan perbuatan yang melanggar hukum dan merugikan masyarakat, sehingga tidak akan mengulanginya dan orang lain juga tidak akan melakukannya mengingat sanksi yang akan ditanggungnya sangat berat.

Sebagai implementasi tindakan represif Satreskrim Polres Pelabuhan Tanjung Perak Surabaya telah melakukan beberapa penindakan terhadap kejahatan jalanan, antara lain dengan menjaring puluhan preman yang tersebar di berbagai wilayah hukum Polres Pelabuhan tanjung Perak Surabaya. Tempattempat dijaringnya preman-preman tersebut antara lain sebagai berikut: a) Pasar Tradisional, merupakan salah satu tempat perekonomian berjalan, karena di dalam pasar terdapat penjual dan pembeli yang melakukan transaksi jual beli. Preman memandang ini sebagai lahan untuk melakukan tindakan kriminalitas karena banyak orang membawa barang berharga. Ataupun melakukan pungutan liar kepada lapak- lapak pedagang; b) Terminal Bus, merupakan tempat yang banyak orang berdatangan ke terminal bus untuk menuju tempat tujuan, hal ini digunakan untuk melakukan tindak kejahatan pada para penumpang bus maupun para supir bus; c) Jalan Raya merupakan tempat umum yang hampir tidak pernah sepi, biasanya pelaku preman melakukan tindak kejahatan pada persimpangan jalan yang tidak ada pengamanan dari polisi, dimana mobil terhenti pada lampu lalu lintas. Biasanya hal ini dilakukan pada malam hari.

Membongkar sindikat kejahatan jalanan dimana pada bulan puasa tahun 2018 lalu banyak pelaku pencurian motor sudah beraksi di Surabaya. Ini terbukti ditangkapnya dua pelaku curanmor oleh Satreskrim Polres Pelabuhan Tanjung Perak. Saat itu Polisi berhasil menangkap dua spesialis curanmor di bulan puasa, KA, dan NW. Keduanya warga jalan Indrapura Jaya Surabaya. Dua pelaku ditangkap saat berada di Warkop jalan Tanjung Layar. Keduanya ditangkap usai mencuri empat motor di Kawasan Johor dan Kalimas Baru. 
Uniknya, kedua pelaku mengaku hanya beraksi di bulan puasa, lantaran saat puasa banyak orang yang lengah. Hal tersebut meruapakan jenis kejahatan dengan tipologi kejahatan situasional. Dari pengembangan pelaku diketahui adanya sindikat curanmor di Surabaya. Dari pengembangan pula Satreskrim Polres Pelabuhan Tanjung Perak Surabaya membekuk sindikat curanmor hasil operasi selama bulan ramadhan dengan mengamankan enam kendaraan roda dua dan tiga tersangka yang beroperasi dalam 10 lokasi.

Menindak tegas dengan tembak di tempat pelaku kejahatan jalanan Untuk situasidan kondisi dapat diberlakukannnya perintah tembak di tempat harus sesuai dengan ketentuan penggunaan senjata api oleh Polri, dimana situasi yang dihadapi adalah situasi dan kondisi yang sesuai dengan keadaan yang terdapat dalam ketentuan penggunaan senjata api oleh Polri, dimana berdasarkan ketentuan tentang penggunaan senjata api oleh Polri perintah tembak di tempat dapat diberlakukan jika terdapat situasi dan kondisi/keadaan yang membahayakan nyawa, atau adanya keadaan yang mengancam (adanya ancaman kejahatan) terhadap kehormatan, harta benda sendiri maupun orang lain.

Situasi dan kondisi dapat diberlakukannya tembak di tempat ini sangat erat hubungannya dengan kapan tembak di tempat dapat diperintahkan, dimana perintah tembak di tempat dapat diturunkan pada saat penangkapan. Untuk penangkapan ini dapat di berlakukan untuk pelaku kejahatan/tersangka yang telah menjadi Daftar Pencarian Orang (DPO) maupun pelaku kejahatan yang tertangkap tangan dan terindikasi membahayakan nyawa orang lain dan nyawa petugas serta terindikasi akan melarikan diri yang mengakibatkan hilangnya tersangka.

Kewenangan tembak ditempat ini tertulis di dalam Pasal 18 ayat (1) Undang-Undang Nomor 2 Tahun 2002 tentang Kepolisian Negara Republik Indonesia berisi: untuk kepentingan umum pejabat Kepolisian Negara Republik Indonesia dalam melaksanakan tugas dan wewenangnya dapat bertindak menurut penilaiannya sendiri. Pasal ini dapat disebut dengan kewenangan diskresi, dalam penerapan di lapangan biasanya Polisi melakukan tindakan tembak ditempat terhadap tersangka. Pada dasarnya pemberlakuan tembak ditempat terhadap tersangka bersifat situasional, yaitu berdasarkan pada Prinsip Proporsionalitas dalam penanggulangan kekerasan dan senjata api harus diterapkan pada saat keadaan tertentu (Arief, 2001).

Sistem represif, tentunya tidak terlepas dari sistem peradilan pidana di Indonesia, dimana dalam sistem peradilan pidana paling sedikit terdapat 5 (lima) sub-sistem yaitu sub- sistem kehakiman, kejaksaan, kepolisian, pemasyarakatan, dan kepengacaraan, yang merupakan suatu keseluruhan yang terangkai dan berhubungan secara fungsional. Upaya represif dalam pelaksanaannya dilakukan pula dengan metode perlakuan (treatment) dan penghukuman (punishment).

Perlakuan (treatment) berdasarkan penerapan hukum, menurut Abdul Syani yang membedakan dari segi jenjang berat dan ringannya suatu perlakuan, yaitu: a) Perlakuan yang tidak menerapkan sanksisanksi pidana, artinya perlakuan yang paling ringan diberikan kepada orang yang belum telanjur melakukan kejahatan. Dalam perlakuan ini, suatu penyimpangan dianggap belum begitu berbahaya sebagai usaha pencegahan; b) Perlakuan dengan sanksi-sanksi pidana secara tidak langsung, artinya tidak berdasarkan putusan yang menyatakan suatu hukum terhadap si pelaku kejahatan.

Adapun yang diharapkan dari penerapan perlakuan-perlakuan ini ialah tanggapan baik dari pelanggar hukum terhadap perlakuan yang diterimanya. Perlakuan ini dititik beratkan pada usaha pelaku kejahatan agar dapat kembali sadar akan kekeliruannya dan kesalahannya, dan dapat kembali bergaul di dalam masyarakat seperti sediakala. Jadi dapat dikatakan bahwa perlakuan ini mengandung dua tujuan pokok, yaitu sebagai upaya pencegahan dan penyadaran terhadap pelaku kejahatan agar tidak melakukan hal- hal yang lebih buruk lagi dimaksudkan agar si pelaku kejahatan ini di kemudian hari tidak lagi melakukan pelanggaran hukum, baik dari pelanggaran- pelanggaran yang mungkin lebih besar merugikan masyarakat dan pemerintah. 
Penghukuman (punishment) diberlakukan jika ada pelanggar hukum yang tidak memungkinkan untuk diberikan perlakuan (treatment), mungkin karena kronisnya atau terlalu beratnya kesalahan yang telah dilakukan, maka perlu diberikan penghukuman yang sesuai dengan perundang-undangan dalam hukum pidana. Oleh karena Indonesia sudah menganut sistem pemasyarakatan, bukan lagi sistem kepenjaraan yang penuh dengan penderitaan, maka dengan sistem pemasyarakatan hukuman dijatuhkan kepada pelanggar hukum adalah hukuman yang semaksimal mungkin (bukan pembalasan) dengan berorientasi pada pembinaan dan perbaikan pelaku kejahatan.

\section{Simpulan}

Tipologi kejahatan di Wilayah Hukum Polres Pelabuhan Tanjung Perak Surabaya antara lain ditinjau dari tipologi tren hidup kriminal Schafer terdiri dari: Penjahat sesekali (20.08 \%), penjahat profesional (79.47 \%), penjahat abnormal (0.43\%). Ditinjau dari Tipologi Kriminal Abrahamsen terdiri dari: kejahatan situasional (36.68\%), kejahatan mekanistis $(23.58 \%)$ serta aksidental (39.73\%). Modus kejahatan jalanan yang dalam hal ini dicontohkan kejahatan curanmor, terdiri dari: modus merampas motor di jalan (26 kejadian), menggunakan kunci T (109 kejadian), menyebar paku di jalan (12 kejadian), berpura pura sebagai pengemudi ojek online (3 kejadian). Faktor timbulnya kejahatan dari sisi pelaku antara lain faktor intern (pendidikan, mental individu) dan faktor ekstern (keadaan ekonomi, keadaan lingkungan, teknologi). Faktor timbulnya kejahatan dari sisi korban diakibatkan karena perilaku korban yang kurang waspada, kondisi biologis dan psikologis korban yang rentan, serta faktor situasi yang mana korban tidak bisa menghadapi situasi saat berhadapan dengan pelaku kejahatan.

Upaya Satreskrim Polres Pelabuhan Tanjung Perak Surabaya dalam menanggulangi kejahatan jalanan antara lain dengan cara preemtif, preventif dan represif. Upaya preemtif dilakukan dengan bekerjasama dengan Binmas untuk mengaktifkan kembali Siskamling yang berguna untuk meningkatkan awarness dari masyarakat akan kejahatan jalanan. Upaya preventif dengan menggalakkan program kring reserse sebagai pedoman pelaksanaan petugas reserse yakni menindak dan merespon tindakan kriminalitas di wilayahnya, serta guna mengantisipasi terjadinya tindak pidana Curi, Curanmor, Curat dan Curas. Upaya represif dilakukan dengan cara menjaring dan memberantas premanisme dan berbagai sindikat kejahatan jalanan, serta menindak tegas dengan tembak di tempat pelaku kejahatan jalanan.

\section{Daftar Pustaka}

Abdulsyani (1987) Sosiologi Kriminalitas. Bandung: CV Remadja Karya.

Allen RC (1996) Socioeconomic conditions and property crime: a comprehensive review and test of the professional literature. American Journal of Economics and Sociology 55 (3) 293-308.

Angkasa \& Iswanto (2005) Viktimologi. Purwokerto: Universitas Jenderal Soedirman.

Arief BN (2001) Masalah Penegakan Hukum dan Kebijakan Penanggulangan Kejahatan. Bandung: PT. Citra Aditya Bakti.

Brady D \& Burton L (2016) The Oxford Handbook of the Social Science of Poverty. Oxfort: Oxford University Press.

Brush J (2007) Does income inequality lead to more crime? A comparison of cross-sectional and time series analyzes of United States counties. Economic Letters 96 (2):264-268.

Choe J (2008) Income inequality and crime in the United States. Economic Letters 101 (1):31-33.

Efendi Y (2005) Kisi-Kisi Krimonologi. Jakarta: Britz Publisher.

Fajnzlber P, Lederman D \& Loayza N (2002) Inequality and violent crime. Journal of Law and Economics 45 (1):1-40.

Imran M, Hosen M \& Chowdhury MAF (2018) Does poverty lead to crime? Evidence from the United States of America. International Journal of Social Economics 45 (10):1424-1438. https://doi.org/10.1108/IJSE-04-2017-0167

Kelly M (2000) Inequality and crime. Review of Economics Statistics 82: 530-539.

Santoso T \& Eva AZ (2005) Kriminologi. Jakarta: PT. RajaGrafindo Persada. 
Setijaningrum E (2017) Program terpadu penanggulangan kemiskinan di Kota Surabaya. Departemen Administrasi Negara Fakultas Ilmu Sosial dan Ilmu Politik Universitas Airlanga. Jurnal Masyarakat Kebudayaan dan Politik 30 (1):14.

Suyanto B (2013) Masalah Sosial Anak. Jakarta: Prenada Media.

Waluyo B (2011) Viktimologi (Perlindungan Saksi dan Korban). Jakarta: Sinar Grafika. 